\title{
VIABILIDADE IN VITRO APÓS VITRIFICAÇÃO DE BLASTOCISTOS DE Mus domesticus domesticus CULTIVADOS A PARTIR DE EMBRIÕES DE 1-CÉLULA
}

\section{IN VITRO VIABILITY AFTER VITRIFICATION OF Mus domesticuts domesticus VLATOCYSTS CULTURED FROM ONE-CELL}

\author{
Leandro Francisco BASILE \\ Orientador: Professor Dr. José Luiz RODRIGUES \\ Departamento de Patologia Animal - UFRGS
}

\begin{abstract}
RESUMO
Foram realizados três experimentos para se avaliar o desenvolvimento in vitro de blastocistos de Mus domesticus domesticus (CF1xSWISS) cultivados a partir de embriões de 1célula, após exposição e vitrificação em solução crioprotetora contendo 9,0 M de EG acrescido ou não de 0,3 M de SAC. No experimento 1, após o cultivo de 755 embriões de 1-célula, foram observadas taxas de eclosão de 53,0\% para o meio HTF e de $61,7 \%$ para o meio KSOM ( $P>0,05)$, suplementados com $4 \mathrm{mg} /$ $\mathrm{ml}$ de BSA + 20 e $25 \mathrm{mM}$ de HEPES. No experimento 2 testaramse os possíveis efeitos tóxicos de soluções crioprotetoras propostas: VS1 $=1,8 \mathrm{M} \mathrm{EG}$ em PBS $+6 \%$ BSA ( $60 \mathrm{~s}$ ) seguido de 9,0 M EG em PBS + 6\% BSA (imersão direta) e VS2 = 9,0 M $E G+0,3$ M SAC em PBS + 6\% BSA (imersão direta) em 152 blastocistos cultivados a partir de embriões de 1-célula em meio KSOM com 25 mM de HEPES. Não houve diferença significativa ( $P>0,05)$ entre os grupos controle $(86 \%)$, VS1 $(82,3 \%)$ e VS2

(78,4\%). No experimento 3, 140 blastocistos cultivados por $72 \mathrm{~h}$ em meio KSOM com $4 \mathrm{mg} / \mathrm{ml}$ modificadas (OPSm) nas soluções crioprotetoras acima descritas, alcançando taxas de eclosão de $45,7$ e $41,4 \%$ para VS1 e VS2 ( $P>0,05)$, respectivamente. Portanto, concluiu-se que ambos os meios, HTF e KSOM acrescidos de BSA e HEPES, proporcionaram o completo desenvolvimento embrionário in vitro. Apesar de não ter ocorrido diferença estatística $(P>0,05)$, no meio KSOM observou-se que os embriões tiveram uma curva de crescimento mais homogênea e melhores taxas de eclosão, representando mais uma alternativa para o cultivo de embriões de 1-célula. Igualmente, não houve variação significativa $(P>0,05)$ nas taxas de eclosão para os blastocistos de Mus domesticus domesticus vitrificados nas soluções crioprotetoras contendo 9,0 M de EG com ou sem o acréscimo de 0,3 M de SAC.
\end{abstract}

\begin{abstract}
Three experiments were carried out in order to evaluate the in vitro development of Mus domesticus domesticus (CF1xSWISS) blastocysts cultured from one-cell embryos after exposition and vitrification in a cryoprotectant solution composed of 9.0 M EG additioned or no of 0.3 M SAC. In the first experiment, after the culture of 755 one-cell embryos, were observed the hatching rates of $53.0 \%$ for HTF medium and $61.7 \%$ for KSOM medium ( $P>0,05)$ supplemented with $4 \mathrm{mg} / \mathrm{ml} \mathrm{BSA}+20$ and $25 \mathrm{mM}$ HEPES, respectively. In the second experiment were evaluated the capacity of the embryos to hatching after exposition to the cryoprotectant solutions proposed (VS1 = 1.8 M EG in PBS + 6\% BSA (120 s) followed by $9.0 \mathrm{M} \mathrm{EG}$ in PBS + 6\% BSA and VS2 = 9.0 M EG + 0.3 M SAC in PBS + 6\% BSA). First the embryos were cultured from one-cell to blastocyst stage and after 152 blastocysts were exposed to the vitrification solutions (VS1 and VS2). The

exposition don't showed significant difference $(P>0.05)$ among the control (86.0\%), VS1 (82.3\%) and VS2 (78.4\%) groups. In the third experiment 140 blastocysts cultured for $72 \mathrm{~h}$ in KSOM with $4 \mathrm{mg} / \mathrm{ml} \mathrm{BSA}+25 \mathrm{mM}$ HEPES were vitrified in $0.25 \mathrm{ml}$ modified straws (OPSm) in the cryoprotectant solutions previously described, reaching hatching rates of 45.7 an $41.4 \%$ in VS1 and VS2 ( $P>0.05)$, respectively. Then, it was concluded that both HTF and KSOM + BSA and HEPES produced a complete in vitro preimplantation embryos development. However, the embryos cultured in KSOM medium showed a homogeneous growing curvature and higher hatching rates, which can be another alternative for culture of onecell embryos. Equally, there were no differences $(P>0.05)$ in the hatching rates between Mus domesticus domesticus vitrified blastocysts in cryoprotectant solutions containing $9.0 \mathrm{~m}$ EG with or without the addition of $0.3 \mathrm{M} \mathrm{SAC}$.
\end{abstract}

